\title{
Community opinion on the personal brand of Bobby Nasution to Prospective Medan Mayor in 2020
}

\author{
Fathur Rahman Panjaitan ${ }^{\mathrm{a}, 1, *}$, Muhammad Said Harahap ${ }^{\mathrm{b}, 2}$ \\ ${ }^{a}$ University of Muhammadiyah Sumatera Utara \\ ${ }^{1}$ fathurrahman2323@gmail.com*; ${ }^{2}$ muhammadsaid@umsu.ac.id; \\ * corresponding author
}

Article history

Received 11-12-2020

Revised 19-12-2020

Accepted 29-12-2020

\section{Keywords}

Public Opinion

Personal Branding

Pilkada

\begin{abstract}
The current phenomenon in the world of politics is flooded with families of politicians who run for politics. Where the next cabinet will be dominated by young people. On the other hand, a young politician, although included in the scope of a political dynasty, shows that young people are not politically apathetic. And to continue to exist in the world of politics, personal branding is needed where every candidate for politicians must build a name or reputation which means creating a "brand" or public perception of them. Bobby Nasution as one of the candidates for the mayor of Medan 2020 tries to create positive personal branding among the people of Medan. This study aims to determine how the public opinion on the personal brand of the 2020 Medan Mayor Candidates. This type of research uses quantitative descriptive research. The population in this study were the people of Tanjung Selamat Subdistrict, Medan Tuntung District, with 100 people as the sample in the study. Data collection techniques in this study were observations and questionnaires (questionnaires). Data analysis in this research is a single table analysis. This research was conducted in the environment III Tanjung Selamat, Medan Tuntung District. When this research was conducted in July 2020. The results of the study, namely personal branding, aim to obtain perceptions that give rise to a positive reputation for the individual. But in fact, the personal brand Bobby Nasution tends to be less than optimal in the Tanjung Selamat Community. This research concludes that Bobby Nasution's brand as a candidate for Mayor of Medan in 2020 raises public opinion and raises the pros and cons of society.
\end{abstract}

This is an open access article under the CC-BY-SA license.

\section{Introduction}

Today in the world of politics, there are many families of politicians who run for politics. Where the next cabinet will be dominated by young people. On the one hand, young politicians, although born from political dynasties, show that the millennial generation is not apathetic towards politics and their concern for politics is important for the sustainability of democracy in Indonesia.

This makes competition in the political world even tighter. One of the most important things that every political candidate needs to do and pay attention to is to listen to the aspirations of the people so that they can continue to exist during intense competition. And to continue to exist in the world of politics, personal branding is needed where every candidate for politicians must build a name or reputation which means creating a "brand" or public perception of them. This is something that needs to be considered because reputation or personal brand is an intangible asset that can provide a large return when the reputation becomes increasingly recognized and trusted by others. This research is about public opinion on Bobby Nasution's personal brand as a candidate for Mayor of 
Medan 2020. This theme is interesting to research because opinions are open answers to an issue, even answers that are stated based on words submitted in writing or orally, and all opinion formation is based on personal experience (frame of experience) and other people's experiences, directly or indirectly known by the individual (frame of reference). There are various kinds of experiences in a person's life, one of which is an experience in facing the local election either for the first time or have experienced several times in choosing a regional head candidate. Therefore, here the researcher wants to explore the opinion of the people of Medan City in interpreting the personal brand of the prospective Medan Mayor, Bobby Nasution.

For politicians, personal branding is the main requirement for politicians to promote themselves as political figures who will advance in the 2020 Medan City elections. One of the candidates running for the Medan City election contest is Bobby Nasution, who is currently a candidate in the regional head elections in particular. his nomination as Mayor of Medan 2020.

If there is little room for mistakes made by regional head candidates, it will have the potential for their electability in the political sphere. Therefore, for politicians and their success teams, it is very important to build an image through personal branding with an effective and efficient communication strategy. As for Bobby Nasution as a candidate for mayor of Medan trying to form a strong and clear image, with a personal brand that is formed in such a way as to package his identity as a native Medan youth, national entrepreneur, President Jokowi's son-in-law to the public in the 2020 Medan City regional head election.

Direct Pilkada is a series of political processes to create a new institution to uphold democracy in the regions. The process in this regional election can minimize the occurrence of widespread political dynastic power exercised by political figures and political parties who have some seats in parliament. Although this pilkada focuses on people's rights, many candidates for the regional head are determined by political parties in the direct elections to be held in 2020 .

Based on the descriptions that have been described the phenomena and academic views that occur, researchers are interested in public opinion on the Personal Brand Candidates for the 2020 Mayor of Medan in the 2020 Medan City Election Candidacy. Because the opinion is a process that combines thoughts, feelings, and suggestions expressed by private citizens, against the policy choices made by government officials. So the researcher wanted to explore the opinion of the people of Medan City in interpreting the personal brand from the personal identity of the candidate for Mayor of Medan, Bobby Nasution, because in his candidacy Bobby Nasution tried to form a strong and clear image, with a personal brand that was formed in such a way as to package his identity as a young person who made changes and improvements for Medan City to the community in the 2020 regional election for the head of Medan City. This study aims to determine how the public opinion on the personal brand of the 2020 Medan Mayor Candidates.

\section{Theorotocal Framework}

\section{1) Public Opinion}

Opinions are opinions, ideas, or the results of human thoughts to explain certain tendencies or preferences towards perspectives and ideologies, but they are not objective because they have not received confirmation or testing. It can also be a statement about something that applies in the future, but the truth or error cannot be immediately determined because sometimes it hasn't gone through the process first (Tosepu, Effendy, \& Bahar, 2015). There are three components as an opinion forming material as follows:

Syahputra (2018) entitled Public Opinion: the concept, formation, and measurement describe seven types of opinion, including: (1)Personal opinion, namely someone's opinion about a problem that occurs in society, (2) Group opinion, namely group opinion on social issues that concern the interests of many people, (3) Majority opinion, namely the majority opinion relating to an issue that is pro, contra, or other assessment, (4) Minority opinion, namely the relatively few opinions related to a social problem, (5) Public opinion, namely the same opinion of all people in society regarding issues of public interest, (6) Mass opinion, namely opinion that is mass in nature, which can turn to destructive physical action if it is not controlled or controlled. 


\section{2) Personal Branding}

As one needs to observe, an example of a product to be recognized, valued requires a brand to give a mark to consumers in terms of the brand so that consumers can be protected as well as producers from other product competitors. The elements that can form personal branding are (Montoya \& Raffaelli, 2010):

Information: (1) You are someone who can be formed in personal branding through wellstructured and planned communication methods, (2) Promise is a promise and responsibility as a standard of commitment to fulfill society, (3) Relationship is an effort to create a good and responsible relationship with the client, According to (Ikhsan, Purwadi, Hariyanto, Heryana, \& Haroen, 2013), the benefits of building personal branding are as follows (Haroen, Marlida, Mirzah, \& Budianyah, 2013).

3) Pilkada

Direct Pilkada is a political breakthrough that has a wide enough impact on the region and society to realize democracy in the local area. Therefore, direct regional elections are a process of strengthening and striving to realize good and effective governance in all aspects of governance (S. Zuhro, 2018). This direct election serves as the people's sovereignty as a realization of democratic principles which includes guarantees of the principle of individual freedom and equality in political rights. The deepening of democracy as stated by Reuschmeyer is an effort to overcome the weaknesses of substantive democratic practice, especially in the aspects of local community demands (R. S. Zuhro, 2010).

The deepening of democracy according to Fung and Olin Wright (R. S. Zuhro, 2010) is also needed to fulfill the central idea of political democracy which includes several important things, such as providing facilities for citizens to be involved in their political participation, encouraging political consensus using dialogue, realizing public policies that can create an effective economy and a healthy society and can also provide protection to citizens so that citizens also enjoy the wealth of the country.

Thus, it can be concluded that in local government, the potential of citizens is not only involved in local elections or seats in parliament but also further to the active involvement of the community at large.

\section{Method}

This type of research uses quantitative descriptive research. The research method used in this study only describes situations or events, does not seek or explain relationships, does not test hypotheses or make predictions. The conceptual framework is a frame of mind that is used as a basis for the momentum of the research perspective as a basis for temporary answers to the problem being tested for truth. The conceptual framework in this study is illustrated through the following chart:

The population in this study were the people of Tanjung Selamat Subdistrict, Medan Tuntungan District, totaling 13,613 people with 6,137 men and 7,476 women. The sample in this study used the Slovin formula to be 100 people (Sugiono, 2016).

\section{Results and Discussion}

This section discusses public opinion about the personal brand of the 2020 Medan Mayor candidate. There are several indicators included in the questionnaire, namely attitudes, beliefs, and perceptions. In this case, what will be concluded is the public opinion on the personal brand of the 2020 Medan Mayor candidate. In this study, the researchers only discussed Bobby Nasution as the 2020 Medan Mayor candidate.

In the nomination of the mayor, a personal brand is needed so that a good image can be formed in the community towards the candidate for mayor and so that the public can get to know the candidate for Mayor who has a strong and clear image. One of the ways used to see the success of a democratic party is to see how public opinion or opinion is about new things in the general election.

Fathur Rahman Panjaitan (Community opinion on the personal brand of Bobby Nasution to Prospective Medan Mayor in 2020) 
The public opinion regarding the personal brand of the candidate for Mayor of Medan Bobby Nasution was carried out by the people of Tanjung Selamat, Medan Tuntung District. In public opinion, this includes belief, namely in Bobby Nasution's competence, attitude, namely whether to accept the character built by Bobby Nasution, the perception that Bobby Nasution's strength in the election for the 2020 Medan Mayor Candidate.

Based on the data from the single table above, it can be concluded that the public opinion on the personal brand of the 2020 Medan Mayor Candidate, especially in this study, the researchers discussed Bobby Nasution, which indeed had positive and negative effects for the community, especially for first-time voters, in this study it can be seen where the most respondents is a man in filling out the questionnaire.

This is because the people of Tanjung Selamat are not familiar with the nomination of Bobby Nasution as a Candidate for Mayor of Medan 2020 where the public knows that Bobby Nasution is the number one son-in-law in the country, not as a Candidate for Medan Mayor. This is because many people consider Bobby Nasution identical to the son-in-law of the number one person in the country, namely President Jokowi. Besides, Bobby Nasution is a candidate for mayor of Medan 2020 who is considered honest and with integrity. This is because the public thinks that Bobby Nasution's figure portrays an honest and integrity figure, but the community is not sure about Bobby Nasution's ability to advance Medan City because he does not have experience in the field of government and his age is still too young.

Besides that, the material strength that supports to become a Candidate for Mayor of Medan is one of the main indicators of Bobby Nasution as a Candidate for Mayor of Medan. From the results of this study, the theoretical conclusion is that having personal branding aims to get a perception that raises a positive reputation for that individual. However, in conclusion from the research results, Bobby Nasution's brand tends to be less than optimal in the Tanjung Selamat Community. This is because the Tanjung Selamat community does not yet know the figure of Bobby Nasution as a candidate for Mayor of Medan 2020. Bobby Nasution's experience, who has never studied politics, also underlies the public's perception. a personal brand does not only form a personal image (image), although the image is the most important thing, it must also be supported by the fact that happens and the power of promise must also be supported by proof.

\section{Conclusion}

From the results and analysis of the research, it can be concluded that the opinion of the public regarding Bobby Nasution's brand is the number one son-in-law in the country, and the average person of the people of Tanjung Selamat, Medan Tuntung District does not yet know that he is a candidate for mayor of Medan 2020. So that looks personal brand Bobby Nasution was not optimal in his candidacy for the mayor of Medan. As for the characteristic dimension, the element of distinctiveness can be seen from the overall opinion of the public who questioned Bobby Nasution as the number one son-in-law in Indonesia who entered politics because of his rising prestige after marrying the president's son.

\section{Acknowledgment}

The author would like to thank profusely to the elements who have helped in completing this research. Thank you also to the Communication Studies Program at the Muhammadiyah University of North Sumatra as a writing institution, as a means of gaining knowledge. 


\section{References}

Haroen, U., Marlida, Y., Mirzah, \& Budianyah, A. (2013). Extraction and isolation phytochemical and antimicrobial activity of limonoid compounds from orange waste juice. Pakistan Journal of Nutrition. https://doi.org/10.3923/pjn.2013.730.735

Ikhsan, M., Purwadi, A., Hariyanto, N., Heryana, N., \& Haroen, Y. (2013). Study of Renewable Energy Sources Capacity and Loading Using Data Logger for Sizing of Solar-wind Hybrid Power System. Procedia Technology. https://doi.org/10.1016/j.protcy.2013.12.293

Montoya, J. M., \& Raffaelli, D. (2010). Climate change, biotic interactions and ecosystem services. Philosophical Transactions of the Royal Society B: Biological Sciences. https://doi.org/10.1098/rstb.2010.0114

Sugiono. (2016). Metode Penelitan Kuantitatif, kualitatif dan R\&D. In Bandung: Alfabeta.

Syahputra, E. (2018). Pembelajaran Abad 21 Dan Penerapannya Di Indonesia. Prosiding Seminar Nasional SINASTEKMAPAN.

Tosepu, R., Effendy, D., \& Bahar, H. (2015). Indonesian strategy in reducing Aedes aegypty diseases in ASEAN economic community era. International Journal of Research in Medical Sciences. https://doi.org/10.18203/2320-6012.ijrms20150232

Zuhro, R. S. (2010). Good Governance dan Reformasi Birokrasi di Indonesia. Jurnal Penelitian Politik.

Zuhro, S. (2018). Demokrasi, otonomi daerah dan pemerintahan indonesia. Interaktif Ilmu-Ilmu Sosial. 